\title{
AVALIAÇÃo DA ILHA DE CALOR URBANA NA ZONA NORTE DE SÃO PAULO: ESTUDO DE CASO DO BAIRRO JARDIM PERI
}

\author{
LIMA, Thiago Luiz - thiago.tlimma@gmail.com \\ Universidade de São Paulo / USP \\ GALVANI, Emerson - egalvani@usp.br \\ Universidade de São Paulo / USP
}

\begin{abstract}
RESUMO: A Ilha de Calor Urbana (ICU) é um fenômeno presente nos centros urbanos causado, principalmente, pelo tipo de uso antrópico do solo. Locais impermeabilizados indicam temperatura do ar mais elevada em relação às áreas rurais ou com maior distribuição vegetativa. Para tanto, o bairro Jardim Peri/SP apresenta características urbanas e naturais, a saber: intensa impermeabilização do solo, retificação de rios, áreas comerciais e áreas arbóreas. Desta forma, o estudo realizado neste bairro por meio de transectos móveis mostrou que a temperatura do ar varia de acordo com o modo de uso e ocupação do solo, indicando temperaturas elevadas dentro da Unidade Microclimática I (UMC I), setor com pouca presença de vegetação, intensa rugosidade urbana e habitações de baixa renda; temperaturas reduzidas na Unidade Microclimática II (UMC II), setor natural serrano de Mata Atlântica; e temperaturas amenas na Unidade Microclimática III (UMC III), setor com intensa distribuição arbórea e habitações de alta renda. Os resultados também indicaram que a variação térmica do bairro num dos três dias de análises chegou a $4,1^{\circ} \mathrm{C}$. Neste sentido, fica notória a relação entre classe social e climatologia no Jardim Peri, uma vez que as condições da vida urbana no bairro expressam uma relação mútua e direta com os fenômenos atmosféricos.
\end{abstract}

PALAVRAS-CHAVe: Transectos Móveis; Jardim Peri; temperatura do ar; uso e ocupação do solo, Ilha de Calor Urbana.

\section{EVALUATION OF THE URBAN HEAT ISLAND IN THE NORTH ZONE OF SÃO PAULO: CASE STUDY OF BAIRRO JARDIM PERI}

ABSTRACT: The urban heat island is a phenomenon present in urban centers caused mainly by the type of anthropic land use. Impermeable areas indicate a higher air temperature compared to rural areas or with major vegetative distribution. The Jardim Peri/SP neighborhood has urban and natural characteristics: intense soil impermeabilization, rectification of rivers, commercial areas and arboreal areas. Therefore, the study conducted in this neighborhood through mobile transects showed that the air temperature varies according to the use and occupation of the soil, indicating high temperatures at the UMC I (sector with less vegetation, intense urban rugosity and low-income habitations); low temperatures at UMC II (mountainous natural sector of the Atlantic Forest); and mild temperatures at the UMC III (sector with intense arboreal distribution and high-income habitations). The results also showed that the thermal variation of the neighborhood in one of the three days of analysis reached $4.1^{\circ} \mathrm{C}$. In this sense, class relations are notorious, since the conditions of urban life in the neighborhood express a mutual and direct relationship with the atmospheric phenomenon.

KEYWORDS: Mobile Transects; Jardim Peri; Air temperature; land use and occupation the soil; Urban Heat Island.

\section{INTRODUÇÃO}

O conceito "ilha de calor" pode ser designado pelas relações humanas/naturais entre a superfície terrestre e a baixa troposfera. Deve-se lembrar que dentro da literatura ainda não está definido de forma exata um 
valor de diferença de temperatura do ar que venha a caracterizar o termo "ilha de calor" (FIALHO, 2012). Neste sentido, o fenômeno Ilha de Calor Urbana (ICU) é evidenciado pela diferença de temperatura entre as áreas urbanas e rurais (GONZALEZ, KRÜGER, 2016). A ICU ocorre por uma conjuntura de fatores introduzida no processo de formação urbana. A cidade intervém no balanço de energia da superfície terrestre principalmente por meio da absorção de energia solar em forma de calor e sua emissão posterior. A presença do fator antropogênico nos locais urbanizados também contribui para este balanço térmico (OKE, 2002). Ou seja, as ações causadas pelo desenvolvimento urbano como a construção de edifícios e a intensa impermeabilização do solo, bem como a presença humana geram condições de balanço térmico superficial das cidades e assim a Ilha de Calor Urbana. Tal fenômeno se relaciona com outros eventos atmosféricos como a precipitação das chuvas e alteração nas amplitudes térmicas que influenciam nas condições de habitação e saúde pública (BARROS, LOMBARDO, 2016).

Outra forma de entender o fenômeno da ICU é o estudo de Carvalho (2001) no qual explica que há três tipos de alterações climáticas causadas pelo processo de urbanização: alteração física das superfícies da terra por meio da intensa impermeabilização do solo; aumento da capacidade de armazenamento de temperatura dos lugares; e a emissão de poluentes. Esses três componentes vinculados à dinâmica atmosférica de energia vão gerar a ilha de calor. Lombardo (1985), Angelocci, Pereira e Sentelhas (2002) também corroboram com esses estudos.

Devido à essa conjuntura espacial, a temperatura do ar atmosférico dos centros urbanos é mais elevada que os locais da sua extremidade. A taxa de calor nos centros urbanos é maior que a taxa de calor das redondezas, gerando maiores temperaturas atmosféricas nas áreas urbanizadas em relação às áreas rurais (NUNES, 2008). Isso se dá, principalmente, pelo tipo de uso e ocupação da terra entre a área central e as suas extremidades. A superfície dos materiais presente nas construções urbanas é diferente daquela encontrada nas áreas rurais. As áreas pavimentadas possuem um determinado índice de absorção e reflexão da radiação solar que difere das áreas rurais. Desta forma, cada lugar terá uma dinâmica térmica atmosférica peculiar onde os materiais sintéticos presentes na malha urbana armazenam energia (radiação solar) por maior tempo, reduzindo a sua capacidade de reflectância, quanto que o contrário ocorre nas áreas rurais ou de maior distribuição arbórea onde os materiais armazenam energia por menor tempo, elevando a sua reflectância (RIBEIRO et. al, 2018). Catuzzo (2013), Berlato et. al (2002), Berbet (2002), Minaki (2012), Gonzales e Krüger (2016) também corroboram com esse estudo.

Foi a partir de 1920 que os estudos do clima nas cidades passaram a ter maior ênfase através do uso de transectos que contribuiu para uma análise espacial da temperatura do ar. Contudo, o método do transecto já era utilizado por Alexander von Humbolt nos séculos XVIII e XIX ao tecer um perfil detalhado da paisagem quanto aos seus aspectos naturais de vegetação, clima e relevo em expedições na América e Ásia. Tal método também foi e ainda é utilizado em diferentes frentes do conhecimento científico: Biologia, Arquitetura, Pedologia, Hidrologia, Geologia, Arqueologia, Engenharia Florestal entre outros (FIALHO, 2018). Na Climatologia Urbana, o transecto móvel é frequentemente utilizado e consiste num percurso feito com veículo coletando amostras de temperatura do ar. Ao longo do tempo, muitos estudos vêm sendo realizados com transectos 
móveis por meio de percursos feitos numa determinada área e/ou rede urbana. Amorim (2005) explica que esta metodologia é uma adaptação dos estudos feitos por Oke e Maxwell (1975); Gomez e Garcia (1984); Johnson (1985); e Pitton (1987).

Segundo dados do último censo do IBGE (2010), o município de São Paulo possui 11.253 .503 habitantes, dentro de uma área de $1.521 \mathrm{~km}^{2}$, com uma densidade demográfica de 7.898,2 hab/ $\mathrm{km}^{2}$, e uma frota com 8.622.427 veículos registrados (Detran, 2018). Como é possível observar, São Paulo concentra um elevado número de habitantes que, consequentemente, causa diversos impactos socioespaciais, sendo um deles a questão da ICU no clima local da cidade.

A partir da conjuntura exposta a respeito da grande aglomeração populacional e da presença da ICU em São Paulo, bem como os seus diferentes modos de uso e ocupação do solo urbano (LOMBARDO, 1985); (BARROS e LOMBARDO, 2016), este artigo busca avaliar e discutir o fenômeno da ICU no bairro Jardim Peri com o objetivo de caracterizar este local como uma Ilha de Calor Urbana dentro da cidade de São Paulo, através das características ambientais que o bairro apresenta e dos dados coletados em campo sobre a temperatura do ar.

\section{A ÁREA DE ESTUDO}

O bairro Jardim Peri está situado na Zona Norte do município de São Paulo dentro do distrito da Vila Nova Cachoeirinha (PREFEITURA DE SÃO PAULO, 2014). O distrito da Vila Nova Cachoeirinha possui uma população com 144.416 pessoas, densidade de 118,35 hab/ha e uma área territorial de 13,5 km2, (Censo IBGE, 2010). Contudo, a prefeitura regional não disponibiliza dados empíricos sobre essas informações do bairro Jardim Peri, uma vez que não há delimitação territorial oficial para o conceito bairro, indicado no mapa 1.

Localização da Área Total de Estudos: Bairro Jardim Peri

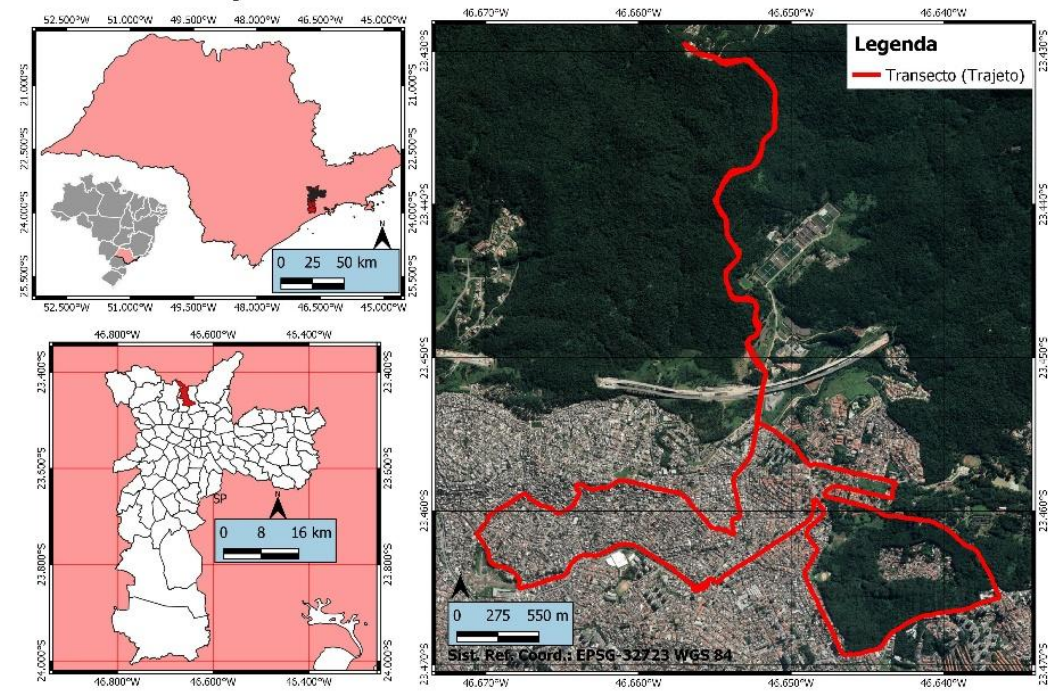

Mapa 1 - Localização da Área de Estudo. Fonte: Google Earth - Organizado pelos autores no software QGIS 
O Jardim Peri foi oficialmente fundado em 5 de maio de 1951 no qual "foi lavrada a certidão de registros de imóveis das terras conforme a Lei n $12.030^{\prime \prime}$ (PREFEITURA DO MUNICİPIO DE SÂO PAULO, 2017). Antes de se tornar um bairro, o Jardim Peri fora parte de duas grandes fazendas da região. Em 1940 foi iniciado o processo de loteamento destas fazendas e a área correspondente ao bairro Jardim Peri foi loteada pelo então empresário Italiano Peri Ronchetti que possuía ligação com a indústria de tecelagem de São Paulo (CÂMARA MUNICIPAL DE SÂO PAULO, 2012). A gleba adquirida à época correspondia a uma área total de 1 milhão de metros quadrados e foi chamada, durante a sua transição, de Bairro Guaraú, pertencendo primeiramente ao $4^{\circ}$ subdistrito de Nossa Senhora do Ó e por fim de Jardim Peri, pertencente ao distrito da Vila Nova Cachoeirinha.

O bairro Jardim Peri está muito próximo à vertente da Serra da Cantareira (extensa área de mata densa natural), bem como possui uma grande favela, sendo que parte dela "configura-se em espaço constituído principalmente de habitações horizontais de baixo padrão em avançado estágio de ocupação clandestina em um terreno linear no fundo de um vale, em área de preservação permanente..." (UTIMURA, 2010, p. 46). No bairro e em seu entorno também há construções de residência de classe média e média alta.

A geomorfologia da área de estudo é formada pela Unidade Morfoestrutural do Cinturão Orogênico do Atlântico e litologia predominante PréCambriana. O relevo apresenta acentuadas formações de morros e cristas que possuem processos geológicos intrusivos que servem de base de sustentação para as elevações, como o caso da serra da Cantareira com altitudes que variam entre 700 e 1200 m (ROSS, MOROZ, 1997); (UTIMURA, 2010).

Com relação ao clima local da área de estudo, pode ser definido com base nos dados das normais climatológicas da Estação Meteorológica do INMET - Mirante de Santana (SP) - coletados entre os anos de 1961-1990 e computados por Tarifa e Armani (2001). A Estação Meteorológica do Mirante de Santana fica a 6 quilômetros da área de estudo. A normal climatológica desta estação demonstra um regime de chuvas e temperaturas do ar característicos desta região.

De acordo com os dados, existem basicamente duas estações bem definidas ao longo do ano: "uma quente e chuvosa de outubro a março, e outra fria e relativamente mais seca de abril a setembro" (UTIMURA, 2010). Os valores médios da temperatura do ar oscilam entre $15,8^{\circ} \mathrm{C}$ e $19^{\circ} \mathrm{C}$ de maio a outubro (estação fria) e $19,7{ }^{\circ} \mathrm{C}$ e $22,4^{\circ} \mathrm{C}$ de novembro a fevereiro (estação quente). A temperatura máxima do ar apresentou valores de $28{ }^{\circ} \mathrm{C}$ durante $\mathrm{O}$ mês de fevereiro e a temperatura mínima $11,7^{\circ} \mathrm{C}$ durante o mês de julho. A média máxima ao longo do ano foi de $24,9{ }^{\circ} \mathrm{C}$ e a média mínima no mesmo período foi de $15,5^{\circ} \mathrm{C}$. A pluviosidade dentro da normal climatológica foi de $1.454,8 \mathrm{~mm}$ precipitados, onde janeiro foi o mês mais chuvoso com $238,7 \mathrm{~mm}$ (período quente) e agosto o mês mais seco com $38,9 \mathrm{~mm}$ (período frio) (TARIFA, ARMANI, 2001).

Uma vez caracterizado o modo pelo qual se comporta a baixa atmosfera no entorno da Estação Meteorológica Mirante de Santana, bem como com base nos estudos de Tarifa e Armani (2001) referentes aos principais controles climáticos do município de São Paulo, podemos caracterizar o local delimitado 
para o estudo como Clima Tropical Úmido Serrano da Cantareira-Jaraguá (TARIFA, ARMANI, 2001); (UTIMURA, 2010).

Quanto às características urbanas, o bairro é majoritariamente residencial com moradias horizontais e poucas áreas verticalizadas. Na avenida principal do bairro, Av. Peri Ronchetti, há um pequeno centro comercial com supermercado, açougues, padarias, lojas de vestuário, bancos, além de bares e restaurantes (PREFEITURA DO MUNICIPIO DE SAO PAULO, 2014).

Outra característica foi o exponencial crescimento populacional do distrito da Vila Nova Cachoeirinha que consequentemente resultou também no aumento populacional do bairro Jardim Peri. Em 1950 o distrito tinha uma população de 32.461 habitantes. Em 1980 havia triplicado para 105.726 e em 2014 chegou a 144.416 habitantes com uma projeção de 150.324 em 2030, segundo o último Censo do IBGE (2010) e SEADE (2014). Esses dados estão representados com mais detalhes na Figura 1.

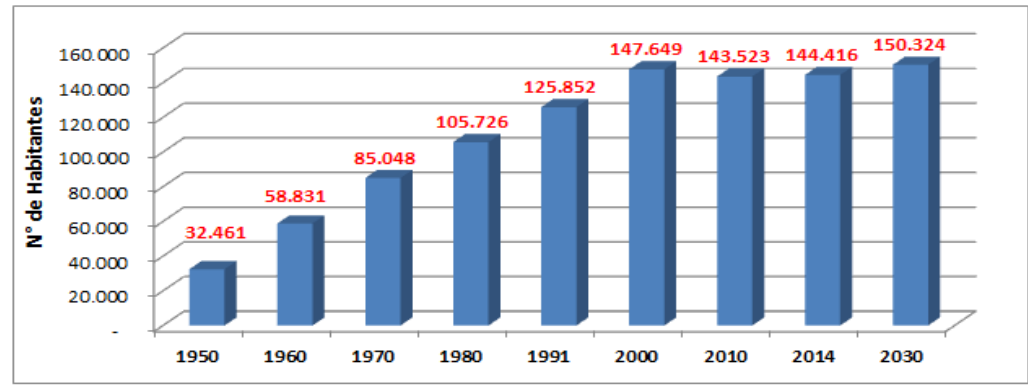

Figura 1 - Evolução Demográfica do Distrito de VI. Nova Cachoeirinha. Fonte: Prefeitura SP, 2019; SEADE, 2014; Censos IBGE, 2019.

\section{MATERIAIS E PROCEDIMENTOS}

Partiu-se da premissa metodológica desenvolvida por Monteiro (1976) sobre o Sistema Clima Urbano, na qual foi realizada uma análise intraurbana onde a observação, descrição e a forma como o espaço se apresenta serviu de base para compreender a sua relação com os sistemas atmosféricos. Este preceito foi desenvolvido sobre a delimitação de uma área territorial (Bairro Jardim Peri) que serviu como objeto de estudo deste trabalho, uma vez que as unidades espaciais climáticas estão diretamente ligadas às unidades geomorfológicas (MONTEIRO, 2003), bem como à reprodução social do entorno.

Desta forma, buscou-se fazer, a priori, uma descrição da paisagem quanto ao tipo de uso e ocupação do solo que se constitui no bairro do Jardim Peri, tentando informar o tipo de habitação presente, a distribuição de vegetação arbórea, os locais com maior e menor concentração de pessoas, veículos, comércios, serviços e fluxos em geral. Em seguida, realizou-se um percurso itinerante dentro do bairro coletando dados empíricos sobre a Temperatura do $\operatorname{Ar}$ (TAR) nos diferentes lugares socioespaciais do bairro. Por último, elaborou-se uma relação entre estes dados e o modo de apropriação social realizado no bairro.

Para a obtenção dos dados sobre a TAR, foi realizado no Jardim Peri um transecto que consiste num percurso feito de carro, conforme indica o Mapa 2. O tempo total do percurso não ultrapassou a média de 48 minutos, assim como 
em outros trabalhos feitos por Amorim (2005), Minaki (2013), Marques et. Al (2009) entre outros onde o tempo do trajeto em suas coletas de campo também não ultrapassou os 60 minutos. O horário do trajeto realizado foi próximo às 20h00min, "horário que as temperaturas não apresentam mudanças rápidas, justamente pela diferença de tempo entre a primeira e a última medida" (diferença de aproximadamente 60 minutos), (AMORIM, 2005, p.6).

Também é possível observar no Mapa 2 a divisão do bairro em 3 setores: Unidade Microclimática I (UMC I); Unidade Microclimática II (UMC II) e Unidade Microclimática III (UMC III). A linha vermelha corresponde ao transecto percorrido com automóvel, ao mesmo tempo que serve como base para traçar os limites entre os três setores (UMC I dentro do quadrante amarelo; UMC II dentro do quadrante verde; e UMC III dentro do quadrante azul). Os pontos beges distribuídos ao longo da linha representam os locais onde ocorreram as coletas de dados atmosféricos (TAR).

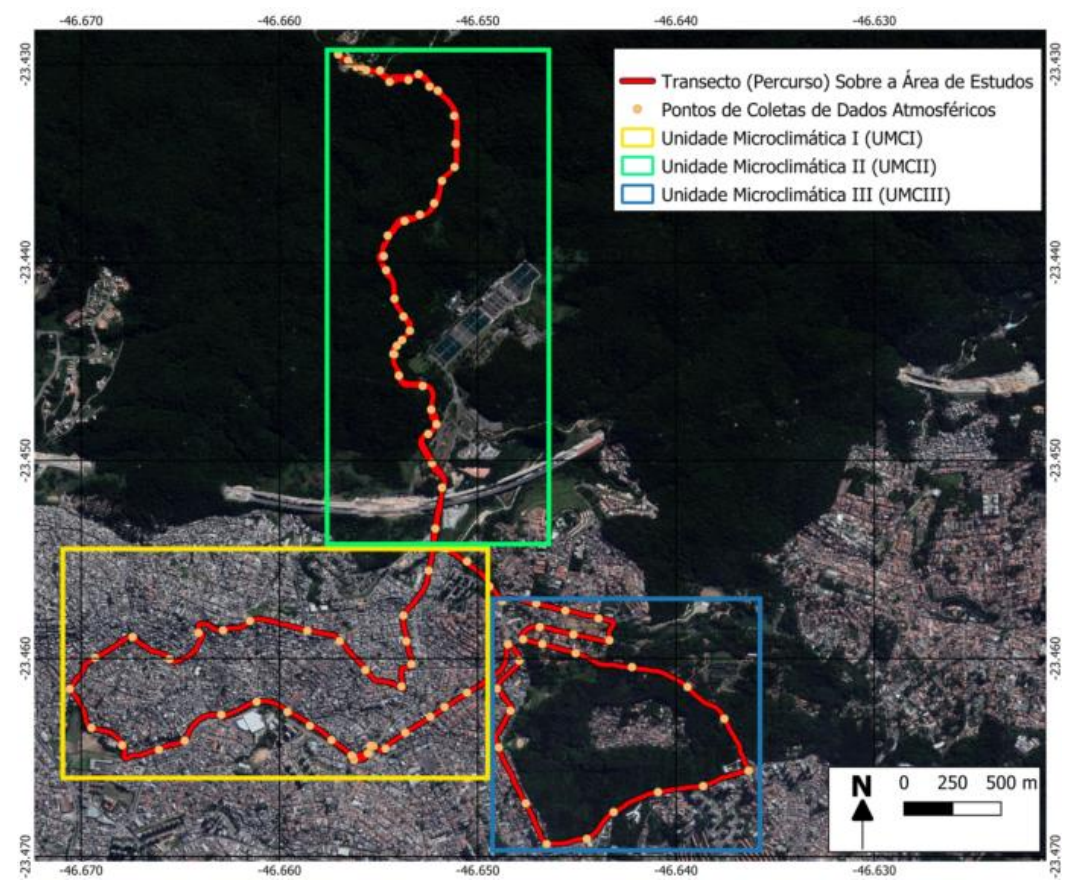

Mapa 2 - Área de Estudos do Jardim Peri: Unidades Microclimáticas I, II e III. Fonte: Google Earth - Organizado pelos autores no software QGIS

A extensão total do transecto é de 19,4 km. O percurso iniciou-se pela Unidade Microclimática I, a Sudoeste da área total de estudo, devido ao seu maior grau de impermeabilização do solo (residências de baixa e média renda; rios retificados; avenidas e ruas pavimentadas; pequeno comércio local). 0 trajeto prosseguiu ao segundo setor, percorrendo a Estrada Santa Inês, região totalmente natural, serrana e de inclinação contínua que apresenta uma paisagem de Floresta Ombrófila Densa Montana da Mata Atlântica, caracterizando, assim, a Unidade Microclimática II ao Norte da área total de estudos. O último trecho do transecto seguiu pelo terceiro setor caracterizado por uma ocupação mista: impermeabilizado com residências de médio e alto padrão, rodeado por florestamento da Mata Atlântica, denominado de Unidade Microclimática III a Sudeste da área total de estudos. 
Os dados atmosféricos sobre a temperatura do ar foram capturados pelo aparelho eletrônico modelo HT-500 da fabricante Instrutherm, pré-programado para coletar as informações de 1 em 1 segundo durante o transecto. O sensor foi instalado no teto do veículo dentro de um mini abrigo metálico de cor branca à uma altura de, aproximadamente, 1,5m, conforme mostra a Figura 2 . 0 equipamento foi disponibilizado pelo Laboratório de Climatologia e Biogeografia (LCB) do Departamento de Geografia da USP.
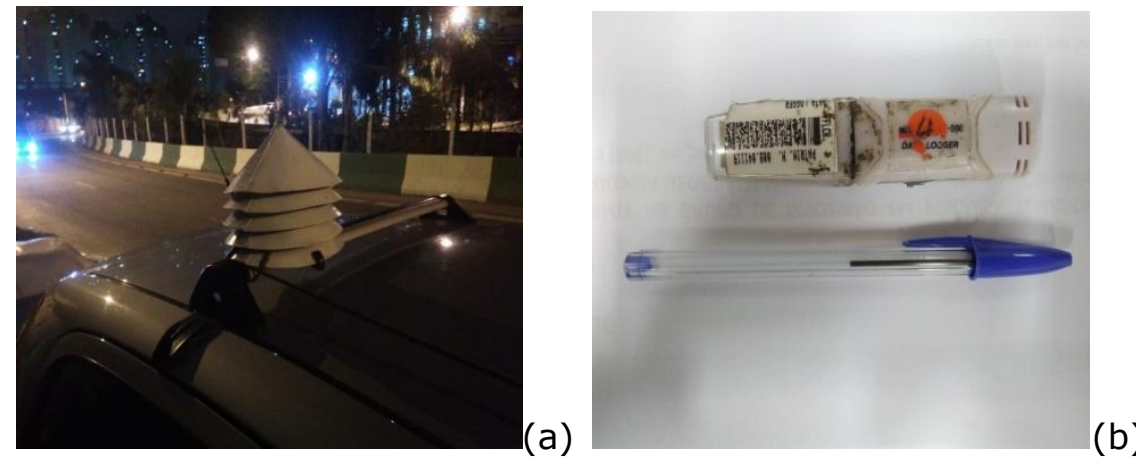

Figura 2 - Mini-abrigo meteorológico de baixo custo (a) e sensor de temperatura e umidade relativa do ar modelo HT-500 instalado dentro do mini-abrigo (b) Fonte: Thiago L. Lima, 18/09/18.

Realizou-se exatamente o mesmo percurso em três dias diferentes, totalizando três transectos: o primeiro em 18 de setembro de 2018 (no inverno); o segundo em 02 de outubro de 2018 (na primavera); e o terceiro em 09 de outubro de 2018 (também na primavera). Os dados sobre a TAR foram todos coletados nos mesmos 102 pontos durante os três dias de coletas, ou seja, o ponto 1 , por exemplo, do percurso realizado no dia 18 de setembro, é o mesmo ponto dos percursos feitos nos dias 02 e 09 de outubro.

Para a marcação dos pontos dentro da área total do bairro Jardim Peri, utilizou-se o programa Google Earth Pro e o aplicativo para celular Geo Tracker, que usa o GPS do aparelho móvel para gravar as coordenadas geográficas do percurso feito no bairro. Ou seja, o GPS foi manuseado juntamente com o sensor HT-500. As coordenadas dos 102 pontos coletadas ao longo do transecto com o Geo Tracker foram descarregadas no programa Google Earth Pro e, posteriormente, compiladas junto aos dados atmosféricos aferidos pelo sensor HT-500 nas planilhas em Excel, servindo de base para a elaboração dos gráficos e dos mapas no programa Quantum Gis.

\section{RESULTADOS E DISCUSSÃO}

No dia 18 de setembro de 2018, terça-feira, a temperatura do ar apresentou valores diferentes nos três setores que compõem a área total de estudos. A Unidade Microclimática I foi caracterizada por indicar as temperaturas do ar mais elevadas, seguida pela Unidade Microclimática III e Unidade Microclimática II, conforme mostra a figura 3. 


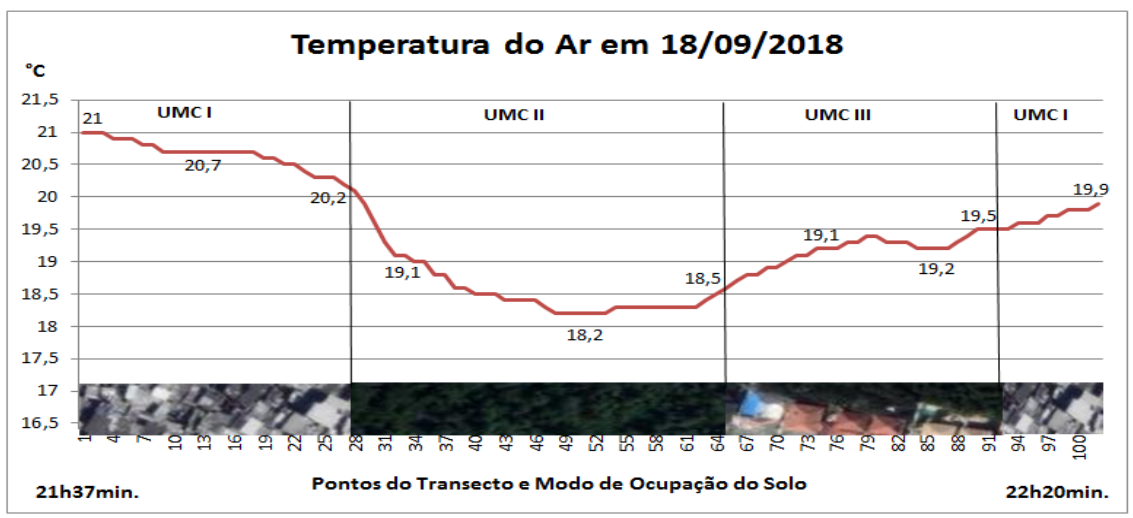

Figura 3 - Variação da temperatura do ar ao longo do transecto realizado em 18/09/18. Fonte: Elaborado pelos autores

A Figura 3 indica que entre os pontos 1 e 3, a temperatura do ar foi a maior de toda a área de estudos com $21^{\circ} \mathrm{C}$ dentro da Unidade Microclimática I (setor com habitações de baixa renda e pouca distribuição arbórea). Em contrapartida, a menor temperatura encontra-se entre os pontos 48 e 53 com $18,2^{\circ} \mathrm{C}$ dentro da Unidade Microclimática II (setor natural de Mata Atlântica). Por fim, as temperaturas amenas encontram-se dentro da Unidade Microclimática III (setor com habitações de alto padrão e intensa distribuição arbórea), oscilando entre a máxima e a mínima da área total de estudos.

Ao se fazer um comparativo entre os setores I e III, percebe-se que a marcação de temperatura no gráfico dentro da UMC III em nenhum momento ultrapassa as temperaturas do ar da Unidade Microclimática I. Isso ocorre devido ao modo de apropriação urbana diferenciada que se faz entre as UMC I e III. Os telhados de zinco e amianto das habitações, bem como a intensa impermeabilização do solo e reduzida distribuição arbórea característicos da UMC I faz com que este setor apresente elevados índices de absorção solar, quanto que o contrário ocorre na UMC III onde os telhados de barro das habitações de alto padrão e a intensa distribuição foliar lhe garantem índices menores de absorção solar, conforme mostram os Mapas 3 e 4.

Ou seja, o tipo de uso e ocupação do solo é o principal indicativo que vai influenciar no balanço energético atmosférico do bairro. Catuzzo (2013) ao realizar um estudo no centro da cidade de São Paulo sobre a influência do telhado verde na dinâmica atmosférica urbana, comprovou que a copa da vegetação pode auxiliar na redução da temperatura do ar, uma vez que o albedo desta superfície apresenta maior reflectância da radiação solar em comparação aos materiais sintéticos da cidade como, por exemplo, o concreto e o asfalto. No caso do Jardim Peri, a diferença da distribuição arbórea entre os setores I e III é um dos fatores por tornar a temperatura do ar na UMC III mais amena quando comparada à UMC I. 


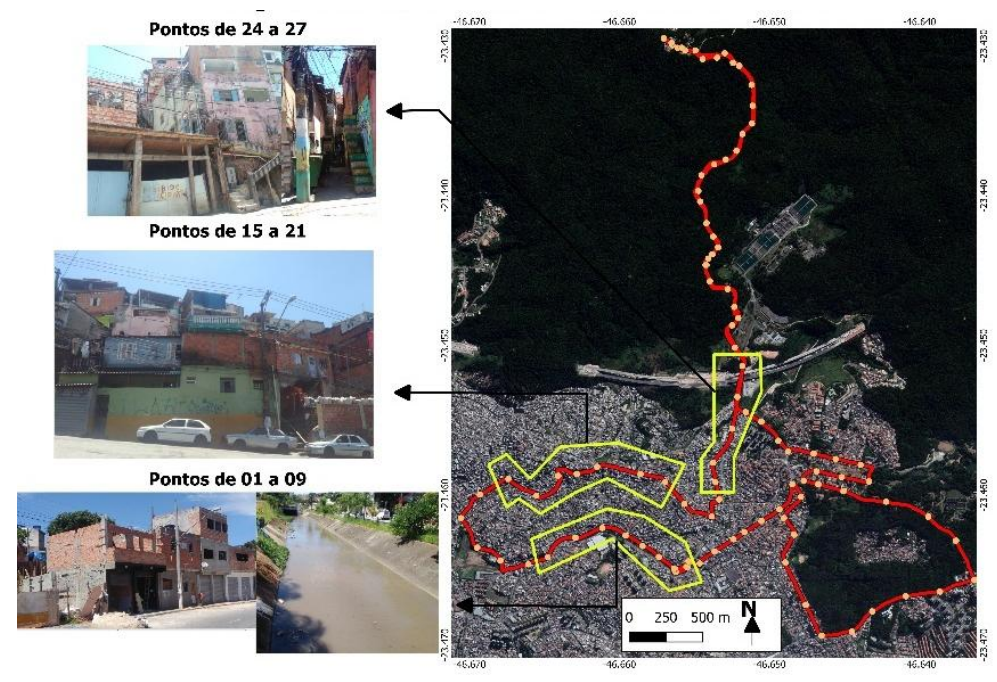

Mapa 3 - Paisagem do Jardim Peri dentro da Unidade Microclimática I.Fonte: Google Earth - Organizado pelos autores no software Qgis.

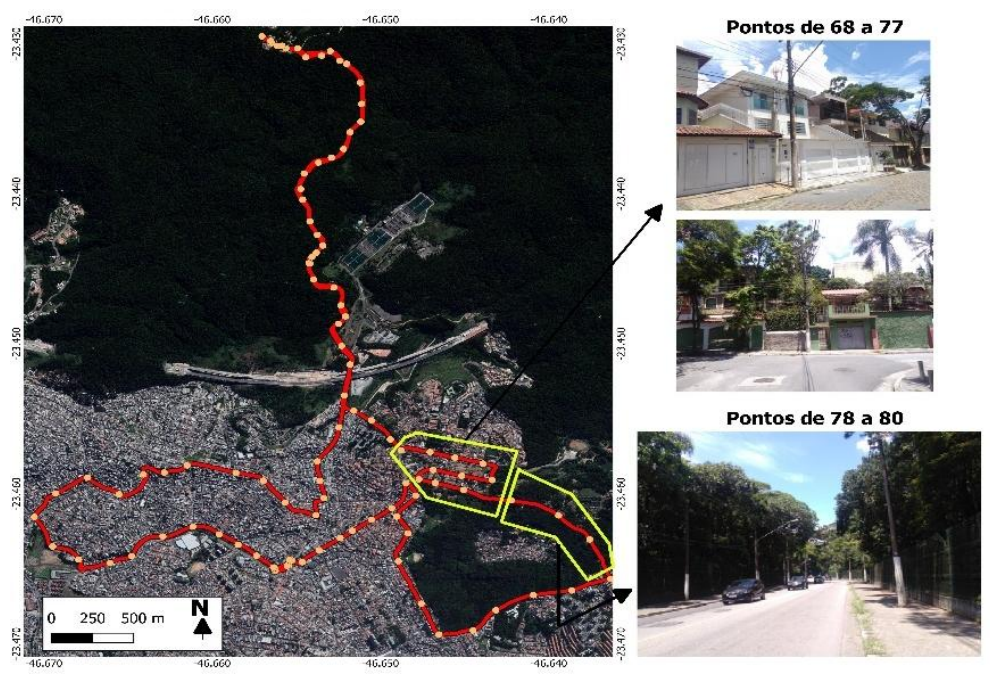

Mapa 4 - Paisagem do Jardim Peri dentro da Unidade Microclimática III. Fonte: Google Earth - Organizado pelos autores no software Qgis.

Outra possibilidade de análise desta situação é examinar as médias da temperatura do ar. Durante o percurso a temperatura média do ar entre os pontos 1 e 27 foi de $20,6^{\circ} \mathrm{C}$. Entre os pontos 28 e 65 foi de $18,5^{\circ} \mathrm{C}$. Entre os pontos 66 e 93 foi de $19,2^{\circ} \mathrm{C}$. E entre os pontos 94 e 102 (trecho final do percurso que volta a entrar nos limites da Unidade Microclimática I) foi de 19,7 ${ }^{\circ} \mathrm{C}$. Desta forma, é possível observar que mais uma vez a conjuntura da temperatura do ar na Unidade Microclimática III encontra-se variando entre as outras duas Unidades Microclimáticas, conforme mostra a Tabela 1. 
Tabela 1 - Temperatura média (Tmed), máxima (Tmax), mínima (Tmin) e variação térmica do ar (VT) ao longo do transecto realizado em 18/09/2018.

\begin{tabular}{|c|c|c|c|c|}
\hline SETOR & $\begin{array}{c}\text { Tmed } \\
\left({ }^{\circ} \mathbf{C}\right)\end{array}$ & $\begin{array}{c}\mathbf{T m a x} \\
\left({ }^{\circ} \mathbf{C}\right)\end{array}$ & $\begin{array}{c}\mathbf{T m i n}\left({ }^{\circ}\right. \\
\mathbf{C})\end{array}$ & $\mathbf{V T}\left({ }^{\circ} \mathbf{C}\right)$ \\
\hline $\begin{array}{c}\text { Unidade Microclimática I } \\
\text { (pontos 1 a 27) }\end{array}$ & 20,7 & 21,0 & 20,2 & 0,8 \\
\hline $\begin{array}{c}\text { Unidade Microclimática II } \\
\text { (pontos 28 a 65) }\end{array}$ & 18,5 & 20,1 & 18,2 & 1,9 \\
\hline $\begin{array}{c}\text { Unidade Microclimática III } \\
\text { (pontos 66 a 93) }\end{array}$ & 19,1 & 19,5 & 18,7 & 0,8 \\
\hline $\begin{array}{c}\text { Unidade Microclimática I } \\
\text { (pontos 94 a 102) }\end{array}$ & 19,7 & 19,9 & 19,5 & 0,4 \\
\hline
\end{tabular}

Fonte: Organizado pelos autores.

A Tabela 1 também indica que a menor variação de temperatura ocorre dentro das Unidades Microclimáticas I e III com uma variação térmica de 0,8 ${ }^{\circ} \mathrm{C}$, exceto no trecho entre os pontos 94 e $102 \mathrm{com}$ variação de $0,4^{\circ} \mathrm{C}$. Por outro lado, a maior variação térmica foi na Unidade Microclimática II com $1,9^{\circ} \mathrm{C}$ causada, principalmente, pela diferença de altitude do relevo dentro desta área, conforme mostra a Figura 4. Neste sentido, vale lembrar que a cada 100 metros de altura na atmosfera, a temperatura do ar diminui, em média, $0,65{ }^{\circ} \mathrm{C}$ (SELLERS, 1974).

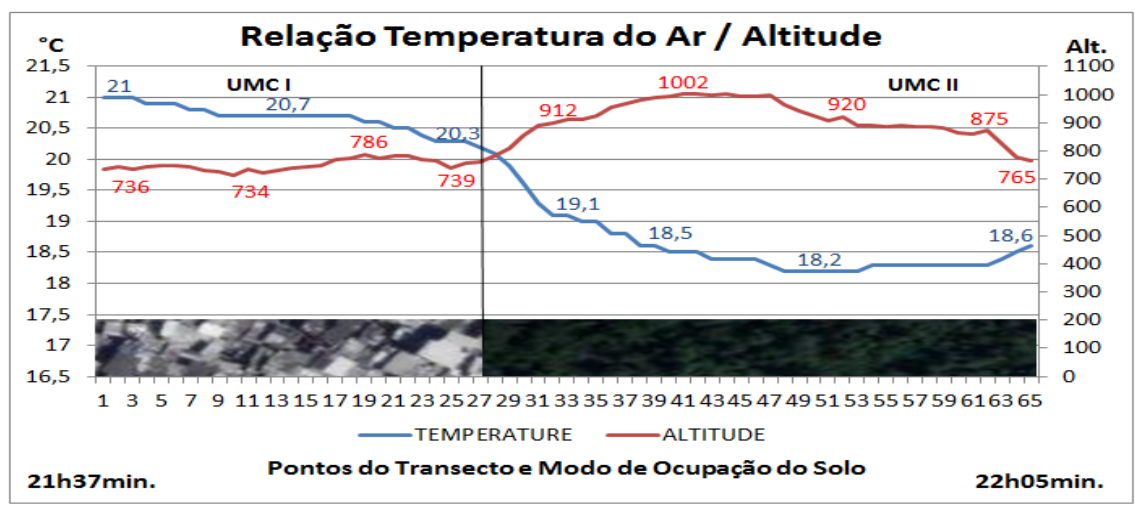

Figura 4 - Variação da temperatura conforme mudança da altitude do terreno em 18/09/18. Fonte: Organizado pelos autores.

Com base entre as temperaturas mínima e máxima do ambiente de estudo, a amplitude térmica ao longo do percurso percorrido foi de $2,8^{\circ} \mathrm{C}$. Em se tratando de uma área de pesquisa de escala reduzida, quase $3^{\circ} \mathrm{C}$ de diferença da temperatura do ar entre os espaços dentro do bairro Jardim Peri é um valor elevado. Isso traz uma problemática para se pensar sobre o modo de uso e ocupação do solo, bem como a distribuição socioespacial que vem sendo feita nesta área ao longo dos anos, impactando diretamente na qualidade de vida dos moradores.

Estes resultados do Jardim Peri se assemelham ao estudo feito em Tupanciretã/RS (WOLLMANN, 2017) que também aplicou o método dos transectos móveis, encontrando diferenças de temperatura de $3{ }^{\circ} \mathrm{C}$, valor muito próximo ao encontrado no Jardim Peri. Em ambas as pesquisas, as áreas rurais ou com maior distribuição foliar são os locais que apresentam as menores temperaturas do ar. Ao contrário, nas áreas com intensa impermeabilização do 
solo e pouca presença de vegetação, as temperaturas do ar são as mais elevadas.

Com relação à UMC III, pode-se inferir que a elevada presença de vegetação neste setor transforma o lugar numa "ilha de frescor urbana", ao utilizar-se como exemplo o estudo feito por Barros (2016) sobre "A Ilha de Calor urbana e o uso e cobertura do solo em São Paulo-SP" que classifica a cidade de São Paulo em Ilha de Calor Forte (áreas com reduzida distribuição foliar), Ilha de Calor Moderada (áreas com moderada distribuição foliar) e Ilha de Frescor (áreas com elevada distribuição foliar). Neste estudo, o autor faz o uso de imagens de satélite para medir o índice de distribuição foliar e a temperatura das superfícies urbanas da cidade de São Paulo. O pesquisador também explica que o índice de distribuição foliar irá influenciar diretamente nesses três tipos de Ilha de Calor: quanto maior a presença de vegetação num dado espaço, menores serão as temperaturas. Por outro lado, quanto menor for a presença de vegetação num espaço determinado, maiores serão as temperaturas.

Neste mesmo estudo, o autor indica que as temperaturas amenas estão situadas nas áreas nobres da cidade de São Paulo. A mesma situação ocorre no Jardim Peri onde as temperaturas mais amenas das áreas urbanizadas do bairro encontram-se no setor de elevada renda econômica. Mesmo sob escalas territoriais diferentes (uma no munícipio e a outra no bairro), tendo cada qual os seus limites de pesquisa, ambas apresentam as mesmas características de classes sociais e climáticas quanto ao tipo de uso e ocupação do solo urbano.

Esta conjuntura também pode ser expressa no mapa de temperatura do bairro Jardim Peri (Mapa 5), onde os valores mais elevados ao longo de todo o transecto $\left(19{ }^{\circ} \mathrm{C}\right.$ a $21^{\circ} \mathrm{C}$ ), foram encontrados dentro da UMC I, com moradias de baixa renda, enquanto que as temperaturas amenas $\left(18^{\circ} \mathrm{C}\right.$ a $\left.19,9^{\circ} \mathrm{C}\right)$, estão dentro da UMC III, com residências de médio e alto padrão e intensa disseminação arbórea.

Jd. Peri: Mapa de Temperatura do Ar (TAR) por Ponto de Coleta em 18/09/18

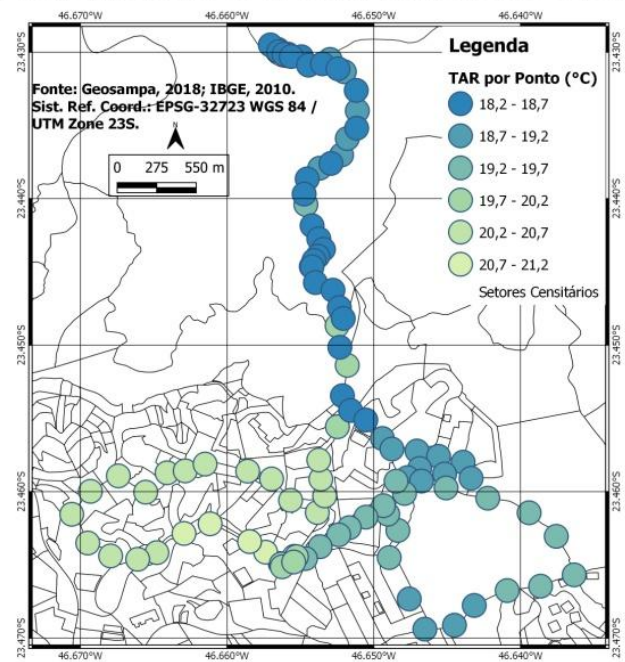

Mapa 5 - Temperatura do Ar ao Longo do Transecto. Fonte: Organizado pelos autores no software Qgis. 


\section{TEMPERATURA DO AR: TRANSECTO DO DIA 02 DE OUTUBRO DE 2018}

No dia 02 de outubro de 2018, terça-feira, a temperatura do ar apresentou o mesmo perfil atmosférico em comparação às coletas do dia 18 de setembro: temperaturas mais elevadas dentro da Unidade Microclimática I; temperaturas mais baixas dentro da Unidade Microclimática II; e temperatura dentro da Unidade Microclimática III com valores que variaram entre os outros dois setores, conforme mostra a Figura 5.

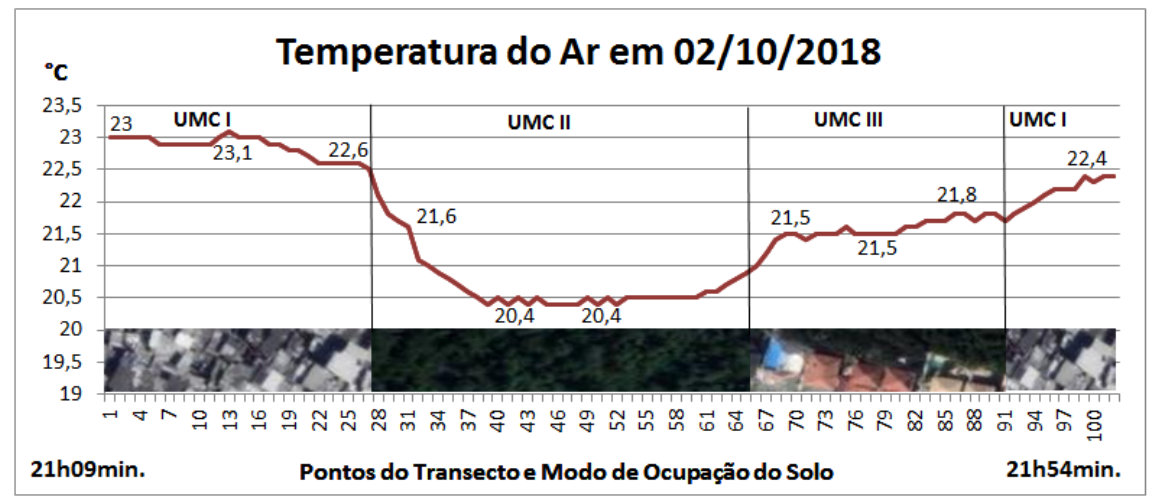

Figura 5 - Variação da temperatura do ar ao longo do transecto realizado em 02/10/18. Fonte: Elaborado pelos autores.

A Figura 5 indica que a maior elevação de temperatura do ar de todo o transecto foi de $23,1^{\circ} \mathrm{C}$ dentro da Unidade Microclimática I no ponto de número 13; a menor temperatura foi de $20,4^{\circ} \mathrm{C}$ na Unidade Microclimática II, nos pontos de número 39, 41, 43, 45 a 48, 50 e 52; e as temperaturas amenas ocorreram dentro da Unidade Microclimática III. Ou seja, a marcação de temperatura da Figura 5 apresentou o mesmo padrão da Figura 3, mesmo com resultados de temperatura do ar coletados em dias alternados, um no dia 18/09 e outro no dia $02 / 10$.

Ao avaliar as temperaturas médias dos três setores da área total de estudos coletados no dia 2 de outubro, foi possível mais uma vez corroborar que a Unidade Microclimática III apresenta temperaturas que oscilam entre os outros dois setores. Conforme indica a Tabela 2, ao longo do transecto a temperatura média do ar entre os pontos 1 e 27 foi de $22,9^{\circ} \mathrm{C}$; a temperatura média do ar entre os pontos 28 e 65 foi de $20,7^{\circ} \mathrm{C}$; a temperatura média do ar entre os pontos 66 e 93 foi de $21,5^{\circ} \mathrm{C}$; e a temperatura média do ar entre os pontos 94 e 102 (trecho final do percurso que volta a entrar na Unidade Microclimática I) foi de $22,2^{\circ} \mathrm{C}$.

A Tabela 2 também indica que a variação térmica de $0,5^{\circ} \mathrm{C}$ da Unidade Microclimática III foi a menor em comparação aos outros setores, exceto no trecho entre os pontos 94 e $102 \mathrm{com} 0,4^{\circ} \mathrm{C}$. Já a maior variação térmica de $1,7^{\circ} \mathrm{C}$ indicada dentro da Unidade Microclimática II se deu devido à elevada altitude que este setor apresenta ao longo do seu transecto, conforme dito no item anterior. Desta forma, os dados da Tabela 2 coletados no dia 02 de outubro seguem a mesma lógica dos dados da Tabela 1 coletados no dia 18 de setembro. 
Tabela 2 - Temperatura média (Tmed), máxima (Tmax), mínima (Tmin) e variação térmica do ar (VT) ao longo do transecto realizado em 02/10/2018.

\begin{tabular}{|c|c|c|c|c|}
\hline SETOR & $\begin{array}{c}\text { Tmed } \\
\left({ }^{\circ} \mathbf{C}\right)\end{array}$ & $\begin{array}{c}\text { Tmax } \\
\left({ }^{\circ} \mathbf{C}\right)\end{array}$ & $\begin{array}{c}\mathbf{T m i n}\left({ }^{\circ}\right. \\
\mathbf{C})\end{array}$ & $\mathbf{V T}\left({ }^{\circ} \mathbf{C}\right)$ \\
\hline $\begin{array}{c}\text { Unidade Microclimática I } \\
\text { (pontos 1 a 27) }\end{array}$ & 22,9 & 23,1 & 22,5 & 0,6 \\
\hline $\begin{array}{c}\text { Unidade Microclimática II } \\
\text { (pontos 28 a 65) }\end{array}$ & 20,7 & 22,1 & 20,4 & 1,7 \\
\hline $\begin{array}{c}\text { Unidade Microclimática III } \\
\text { (pontos 66 a 93) }\end{array}$ & 21,5 & 21,9 & 21,4 & 0,5 \\
\hline $\begin{array}{c}\text { Unidade Microclimática I } \\
\text { (pontos 94 a 102) }\end{array}$ & 22,2 & 22,4 & 22,0 & 0,4 \\
\hline
\end{tabular}

Fonte: Produzido pelos autores.

Com base entre as temperaturas mínima e máxima do transecto feito no dia 02 de outubro, a variação térmica ao longo do percurso percorrido foi de $2,7^{\circ} \mathrm{C}$, muito próximo da variação térmica do transecto realizado duas semanas antes no dia 18 de setembro com o valor de $2,8^{\circ} \mathrm{C}$. O Mapa 6 demonstra esta variação no qual as temperaturas elevadas $\left(22,3^{\circ} \mathrm{C}\right.$ a $\left.23,1^{\circ} \mathrm{C}\right)$ se situam dentro da UMC I; as menores temperaturas $\left(20,4^{\circ} \mathrm{C}\right.$ a $\left.21,2{ }^{\circ} \mathrm{C}\right)$ se encontram dentro da UMC II; e as temperaturas amenas $\left(21,2^{\circ} \mathrm{C}\right.$ a $\left.22,3^{\circ} \mathrm{C}\right)$ estão dentro da UMC III. Ou seja, essas temperaturas possuem uma correlação direta quanto ao modo de uso e ocupação do solo, bem como o tipo de classes sociais também desiguais presentes nestes setores.

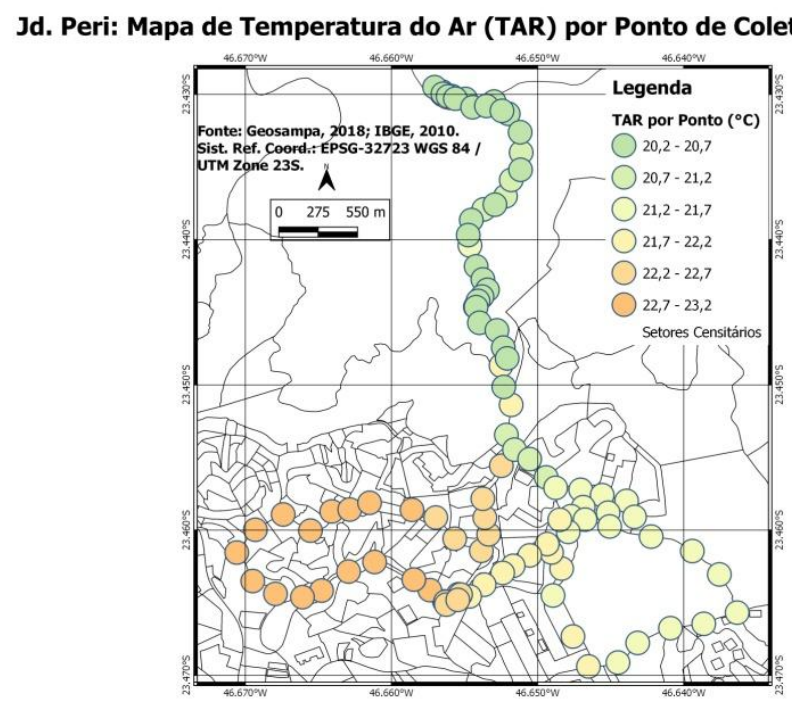

Mapa 6 - Temperatura do Ar ao Longo do Transecto. Fonte: Organizado pelos autores no software Qgis.

Uma forma de corroborar os resultados do Jardim Peri vistos no Mapa 6 seria comparando-os à pesquisa de Amorim (2005) feito em Presidente Prudente/SP também por meio da metodologia dos transectos móveis, com a diferença de que, no estudo de Presidente Prudente, a autora realizou dois transectos simultaneamente perpendiculares em 5 dias diferentes. Em contrapartida, no Jardim Peri foi feito o uso de apenas um transecto em 3 dias diferentes. Todavia, os resultados foram os mesmos em ambas as pesquisas onde as áreas urbanas de Presidente Prudente e do Jardim Peri indicaram 
temperaturas do ar mais elevadas em comparação às áreas rurais e naturais, respectivamente.

O mesmo estudo com metodologias semelhantes foi realizado por Minaki (2013) na cidade de Araçatuba/SP. Assim como a pesquisa feita em Presidente Prudente pela Amorim (2005), a autora realizou dois transectos simultaneamente. Considera que o processo de modificação da cidade de Araçatuba provocada pelo crescimento urbano contribuiu para a formação de um clima urbano. Em algumas coletas, a amplitude térmica chegou a $5,9^{\circ} \mathrm{C}$ entre as áreas periféricas com presença de vegetação e a área central da cidade com pouca vegetação disseminada e intensa impermeabilização do solo. As pesquisas de Minaki, Amorim e deste trabalho apresentam resultados com o mesmo padrão na formação da Ilha de Calor Urbana.

\section{TEMPERATURA DO AR: TRANSECTO DO DIA 09 DE OUTUBRO DE 2018.}

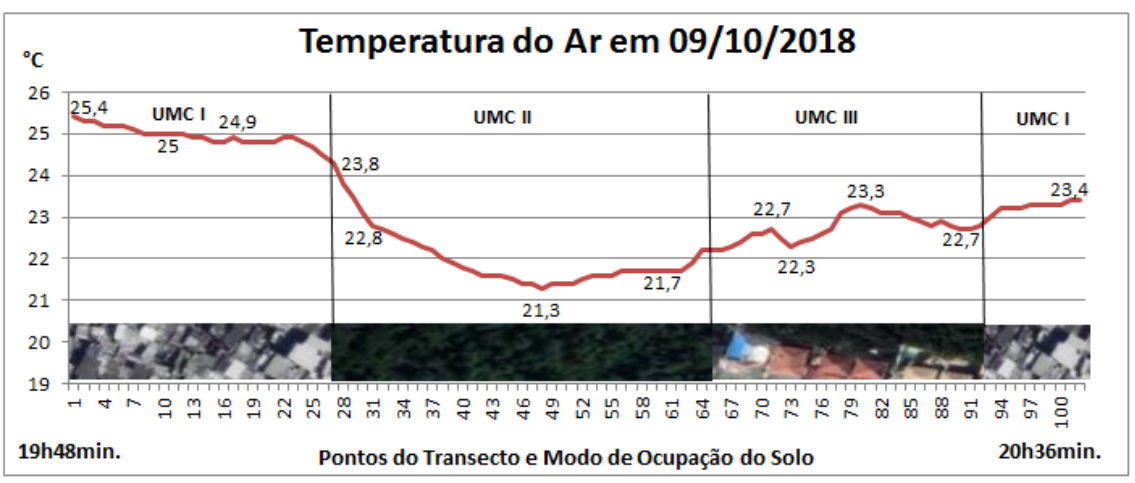

Figura 6 - Variação da temperatura do ar ao longo do transecto realizado em 09/10/18. Fonte: Elaborado pelos autores.

Assim como nas análises dos outros dois dias, a variação da temperatura do ar acompanha a mudança da paisagem do terreno ao longo de todo o transecto. Conforme mostra a Figura 6 , do ponto 1 ao 24 a temperatura apresenta uma leve perda, passando de $25,4^{\circ} \mathrm{C}$ para $24,8^{\circ} \mathrm{C}$, diminuindo $0,6^{\circ} \mathrm{C}$. Entre os pontos 25 e 48, a redução da temperatura do ar é mais acentuada, passando dos $24,7^{\circ} \mathrm{C}$ para $21,3^{\circ} \mathrm{C}$, uma perda de $3,4^{\circ} \mathrm{C}$. Mais uma vez essa diferença se dá, principalmente, pela altitude elevada da Unidade Microclimática II que vinculada a total presença de vegetação acaba por tornar este local um ambiente de baixas temperaturas quando comparado aos outros dois setores. A partir do ponto 49 ao 71 a temperatura do ar aumentou de $21,4{ }^{\circ} \mathrm{C}$ para 22,3 ${ }^{\circ} \mathrm{C}$. Em seguida, houve um pequeno trecho em que a temperatura do ar diminuiu e novamente voltou a subir até o ponto 80 . A temperatura volta a cair até o ponto 91 e depois aumenta sem muita variação até o final do percurso no ponto 102.

É possível perceber que dentro da Unidade Microclimática III a temperatura do ar apresentou muitas variações, aumentando e diminuindo os seus valores. Todavia, mesmo com muitas oscilações, este setor manteve as suas temperaturas abaixo das temperaturas do setor I. O Mapa 7 apresenta essas variações no qual as temperaturas mais elevadas $\left(23,8{ }^{\circ} \mathrm{C}\right.$ a $25,4{ }^{\circ} \mathrm{C}$ ) se situam dentro da UMC I; as menores temperaturas $\left(21,3^{\circ} \mathrm{C}\right.$ a $\left.22,4{ }^{\circ}\right)$ se encontram dentro da UMC II; e as temperaturas amenas $\left(22,4{ }^{\circ} \mathrm{C}\right.$ a $\left.23,8{ }^{\circ} \mathrm{C}\right)$ 
estão dentro da UMC III. Logo, os Mapas 8, 9 e 10 apresentam semelhanças muito intrínsecas.

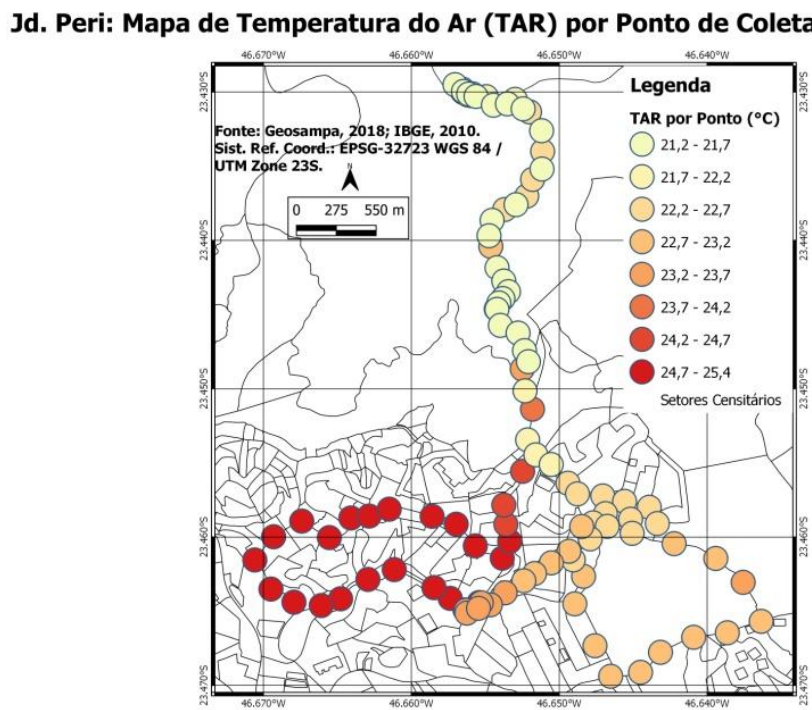

Mapa 7 - Temperatura do Ar ao Longo do Transecto. Fonte: Organizado pelos autores no software Qgis.

Tabela 3 - Temperatura média (Tmed), máxima (Tmax), mínima (Tmin) e variação térmica do ar (VT) ao longo do transecto realizado em 09/10/2018.

\begin{tabular}{|c|c|c|c|c|}
\hline SETOR & $\begin{array}{c}\text { Tmed. } \\
\left({ }^{\circ} \mathbf{C}\right)\end{array}$ & $\begin{array}{c}\text { Tmáx. } \\
\left({ }^{\circ} \mathbf{C}\right)\end{array}$ & $\begin{array}{c}\text { Tmín. } \\
\left({ }^{\circ} \mathbf{C}\right)\end{array}$ & $\begin{array}{c}\text { VT. } \\
\left({ }^{\circ} \mathbf{C}\right)\end{array}$ \\
\hline $\begin{array}{c}\text { Unidade Microclimática I (pontos } \\
\text { 1 a 27) }\end{array}$ & 24,9 & 25,4 & 24,3 & 1,1 \\
\hline $\begin{array}{c}\text { Unidade Microclimática II } \\
\text { (pontos 28 a 65) }\end{array}$ & 21,9 & 23,8 & 21,3 & 2,5 \\
\hline $\begin{array}{c}\text { Unidade Microclimática III } \\
\text { (pontos 66 a 93) }\end{array}$ & 22,7 & 23,3 & 22,2 & 1,1 \\
\hline $\begin{array}{c}\text { Unidade Microclimática I } \\
\text { (pontos 94 a 102) }\end{array}$ & 23,3 & 23,4 & 23,2 & 0,1 \\
\hline
\end{tabular}

Fonte: Produzido pelos autores.

Conforme aponta a Tabela 3, a temperatura média do ar no terceiro setor variou entre a média das Unidades Microclimáticas I e II. Este fenômeno ocorreu exatamente da mesma maneira nos três dias de coletas da temperatura do ar. Isso aponta que o modo de uso e ocupação do solo no terceiro setor com casas de alto padrão e intensa distribuição foliar (o oposto da Unidade Microclimática I com moradias precárias de baixa renda e pouca vegetação dissipada) pode ser um condicionante influenciador na temperatura do ar mais amena. A tabela também indica que a temperatura máxima no primeiro setor (pontos entre 1 e 27) foi de $25,4^{\circ}$ e no terceiro setor foi de $23,3^{\circ} \mathrm{C}$, uma diferença de $2,1^{\circ} \mathrm{C}$. Também fica notória a variação térmica de $4,1^{\circ} \mathrm{C}$ entre a temperatura máxima e mínima ao longo de todo o transecto; é a maior variação das três coletas realizadas.

Ao se fazer um comparativo à pesquisa desenvolvida por Marques et. Al (2009) na cidade de Coimbra (Portugal) onde também se aplicou o método de transectos móveis, os resultados da temperatura do ar encontrados tanto no 
Jardim Peri quanto em Coimbra foram muito semelhantes. Uma das observações realizada com um veículo em Coimbra no dia 21/04/09, início da primavera na Europa (no Jardim Peri, a primeira observação foi coletada no final do inverno e as outras duas no começo da primavera), próxima às $22 \mathrm{~h} 00 \mathrm{~min}$ (horário próximo das coletas realizadas no bairro do Jardim Peri), identificou um núcleo principal de Ilha de Calor Urbana nos espaços com maior urbanização, apresentando uma diferença térmica do ar entre o urbano e o rural de $3^{\circ} \mathrm{C} / 4^{\circ} \mathrm{C}$. Ou seja, Coimbra manifestou amplitudes térmicas muito semelhantes às encontradas no bairro do Jardim Peri que no dia 09 de outubro foi de $4,1^{\circ} \mathrm{C}$.

Os resultados da pesquisa de Marques et. al (2009) também indicam que a região caracterizada como Ilha de Frescor Urbano (temperaturas mais amenas) está inserida no local onde se situa um jardim botânico em meio à malha urbana. No caso do Jardim Peri, o local com temperaturas do ar mais amenas encontra-se dentro da Unidade Microclimática III que, apesar de não ser um jardim botânico, possui as mesmas características do mesmo com intensa presença de vegetação distribuída ao entorno das habitações. Ou seja, Mesmo com diferentes escalas de estudos (Jardim Peri sendo topo climático e Coimbra sendo local) (MONTEIRO, 2003), em localizações diferentes (Jardim Peri na latitude $23^{\circ} 32^{\prime}$ e Coimbra na latitude $40^{\circ} 12^{\prime}$ ) e com variadas influências macro climáticas (Jardim Peri em zonas tropicais e Coimbra em zonas temperadas), ambas apresentam semelhanças na variação da temperatura do ar quando se observa o tipo de uso e o modo de apropriação do espaço urbano.

Outro estudo com resultados muito parecidos com o caso do Jardim Peri é a pesquisa de Fialho e Rocha (2010) promovida em Viçosa/MG ao correlacionar as coletas de temperatura do ar com o tipo de uso e ocupação da terra. A paisagem ao longo desses pontos apresenta diferentes aspectos urbanos como campos de pastagem, áreas de Mata Atlântica natural, residências unifamiliares em locais de reduzida densidade populacional e intensa presença de edificações comerciais no centro da cidade com grande fluxo de veículos e pessoas. Isto é, do ponto de vista sobre o tipo de uso e ocupação do solo encontrado em Viçosa, essas características são muito parecidas ao espaço urbano encontrado no Jardim Peri. Com relação aos resultados, os autores informam que as temperaturas do ar mais elevadas na cidade de Viçosa, segundo as pesquisas de campo feitas também com transectos em 5 dias diferentes durante a primavera de 2010, foram encontradas na região central do município e que a capacidade de dispersão de calor neste local era muito reduzida principalmente em situações sinóticas "com noites de céu claro (sem nuvens) e ventos calmos" (FIALHO, ROCHA, 2010, p. 72). Da mesma forma, no bairro do Jardim Peri, as pesquisas de campo mostram que as temperaturas mais elevadas foram encontradas dentro da Unidade Microclimática I nos três dias de coleta dos dados com características espaciais de intensa impermeabilização do solo e reduzida presença de vegetação.

Por outro lado, na cidade de Viçosa, as temperaturas do ar mais baixas foram encontradas nas áreas da Universidade Federal de Viçosa (UFV) e na região conhecida como Mata do Paraíso - Novo Silvestre que fica próxima à Zona da Mata do estado de Minas Gerais. Fialho e Rocha (2010) explicam que nesses lugares a intensa presença de áreas verdes e corpos d'águas aumentam as taxas de resfriamento, auxiliando na dissipação de energia. O mesmo fenômeno ocorre no bairro Jardim Peri onde as menores temperaturas do ar foram encontradas dentro da Unidade Microclimática II cujo relevo de serra é 
encoberto por uma vegetação natural de Mata Atlântica Ombrófila Densa Montana.

Essas semelhanças se fazem ainda mais notórias ao ser verificar-se a localização das áreas mais aquecidas de Viçosa e do bairro Jardim Peri. Tanto o centro urbano da cidade de Viçosa quanto a Unidade Microclimática I do Jardim Peri situam-se num relevo de várzea, ou seja, em baixas altitudes. Por este motivo, a coluna de ar atmosférico sobre estes terrenos é maior, podendo propiciar situações atmosféricas estáveis onde à circulação de ar se torna muito reduzida com pouca capacidade de dispersão de energia. Desta forma, essas áreas apresentam "dificuldades em dissipar a energia que vem sendo acumulado ao longo do dia em função, sobretudo, do processo de urbanização e do ritmo das atividades antrópicas que se expressam nesses locais" (FIALHO, ROCHA, 2010, p. 74). O Mapa 8 explica esta dinâmica atmosférica ao fazer a correlação entre a TAR e o relevo do Jardim Peri, demonstrando que as TAR elevadas se encontram nas baixas cotas altimétricas do bairro, à Sudoeste, dentro da UMC I. Em contrapartida, as menores TAR se situam nos pontos elevados do terreno, à Leste e, principalmente, por toda a região Norte serrana. O fenômeno ocorreu de forma muito semelhante nos 3 dias de pesquisa, em 18/09/18, 02/10/2018 e 09/10/2018.

\section{Relação Temp. Ar/Relevo do Bairro Jardim Peri}
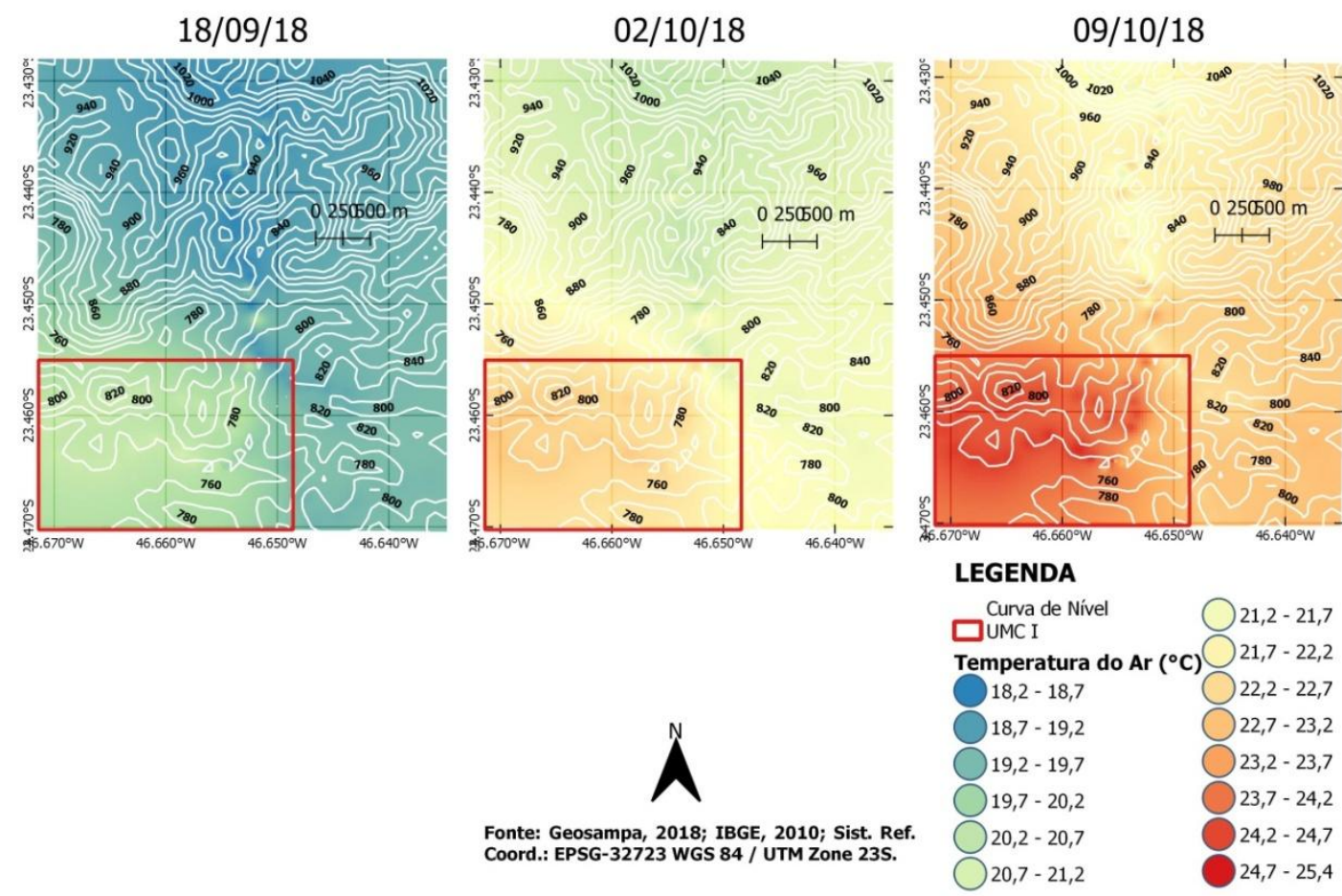

Mapa 8 - Temperatura do ar e o padrão de relevo. Fonte: Organizado pelos autores no software Qgis.

Outra forma de visualizar essas informações se faz também ao sobrepor os resultados dos três dias de pesquisa do Jardim Peri num mesmo gráfico, onde fica claro o padrão que existe entre eles. Conforme indica a Figura 7, os três dias de coleta de dados apresentam temperaturas do ar elevadas dentro da Unidade Microclimática I; temperaturas do ar baixas dentro da Unidade 
Microclimática II; e temperaturas do ar amenas dentro da Unidade Microclimática III.

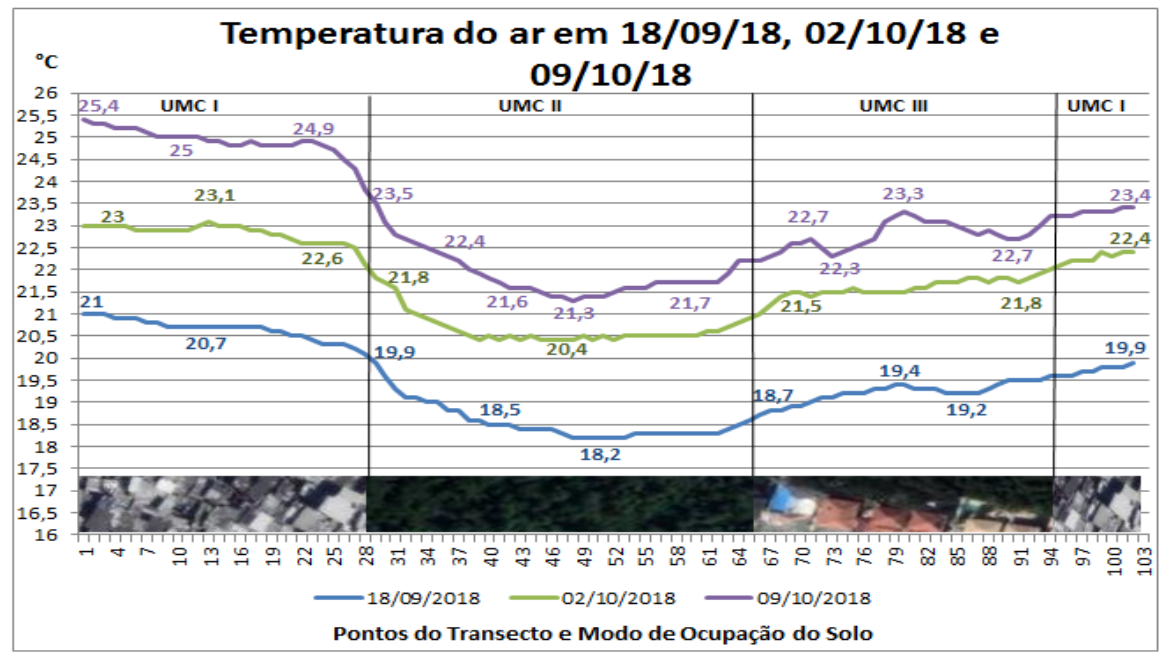

Figura 7 - Variação da temperatura do ar ao longo do transecto realizado em 18/09/18, 02/10/18 e 09/10/18. Fonte: Elaborado pelos autores.

Por fim, este estudo indica que o contexto urbano (relevo, ocupação humana e o seu modo de apropriação) possui uma correlação direta com os resultados apresentados, no qual o processo de urbanização interfere diretamente no balanço energético atmosférico do bairro.

\section{CONCLUSÕES}

Os resultados deste trabalho indicam que uma determinada área do Jardim Peri possui temperatura do ar elevada em comparação ao seu entorno, chegando à variação máxima de $4,1^{\circ} \mathrm{C}$, caracterizando, assim, uma Ilha de Calor Urbana dentro da cidade de São Paulo na sua face Norte.

A área identificada como uma Ilha de Calor Urbana do Jardim Peri foi o setor denominado de Unidade Microclimática I. Esta unidade apresentou as maiores temperaturas do ar nos três dias de coleta dos dados em campo. Os outros dois setores, Unidades Microclimáticas II e III, apresentaram temperaturas do ar mais amenas, principalmente o primeiro setor, onde foram encontradas as menores temperaturas nos três dias de pesquisa devido a sua paisagem de serra encoberta por Mata Atlântica Natural Ombrófila Densa Montana.

Desta forma, a Ilha de Calor Urbana definida no bairro tem como atributo central os efeitos antrópicos de uso e ocupação do solo, no qual a intensa impermeabilização do terreno, a distribuição desigual da vegetação, os diferentes tipos de habitações e os seus materiais como telhados de zinco, amianto entre outros vão interagir diretamente no balanço energético da atmosfera. Tal conjuntura sistêmica demonstrou o seu impacto na temperatura do ar que pode trazer diferentes condições de vida à comunidade local, uma vez que a população de baixa renda reside dentro da Ilha de Calor, frente à população de alta renda que vive numa área com temperatura do ar amena. 
Logo, se faz necessária a presença dos órgãos públicos competentes para que em conjunto com a população se defina planejamentos urbanos no tocante aos temas relacionados à, principalmente, habitação e meio ambiente.

\section{REFERÊNCIAS BIBLIOGRÁFICAS}

AMORIM, C. C. T. Margarete. Intensidade e Forma da Ilha de Calor Urbana em Presidente Prudente/SP: Episódios de Inverno. Geosul Florianópolis, v. 20, n. 39, p 65-82, jan./jun. 2005.

AMORIM, C. C. T. Margarete; e MINAKI, Cíntia. Características das Ilhas de Calor em Araçatuba/SP: Análise de Episódios. rev. Geonorte, V. 2, N. 5, p. 279 - 394, 2012.

ANGELOCCI, R. L; PEREIRA, R. A; SENTELHAS, C. P. Agrometeorologia: Fundamentos e Aplicações Práticas. ed. Agropecuaria, Guaíba, RS, 2002.

ARMANI, G; TARIFA, Junior. Os Climas "Naturais". In TARIFA, J. e AZEVEDO, T. R. (org). Os Climas na Cidade de São Paulo. GEOUSP, São Paulo, 2001.

BARROS, R. Hugo; LOMBARDO, A. Magda. A Ilha de Calor Urbana e o Uso e Cobertura do Solo em São Paulo-SP. Geousp - Espaço e Tempo (Online), v 20, n. 1, p. t70-177, 2016.

BERBET, L. C. Meire. Variação Sazonal do Albedo e sua Influência na Mudança do Padrão de Chuva, em Consequência da Conversão da Floresta Tropical em Pastagem. Tese pós-graduação UFV, Viçosa-MG, 47 p, 2002.

BERLATO, M; CARDOSO, L; FONTANA D; LEIVAS J. Variação Diário do Albedo Sobre uma Superfície Vegetada e Sobre um Lago na Estação Experimental da UFRGS-RS. XV Congresso Bras. de Agrometeorologia - Aracaju-SE, 2007.

CARVALHO, M. M. Clima Urbano e Vegetação: Estudo Analítico e Prospectivo do Parque das Dunas em Natal. Dissertação de Mestrado em Arquitetura e Urbanismo, Natal-RN, 2001.

CATUZZO, H. Telhado Verde: Impacto Positivo na Temperatura e Umidade do Ar. O Caso da Cidade de São Paulo. Tese (Doutorado em Geografia Física) Faculdade de Filosofia, Letras e Ciências Humanas, Universidade de São Paulo, São Paulo, 2013.

DANTAS, A.S.L. Geologia da faixa São Roque e intrusivas associadas na região entre São Paulo e Mairiporã, norte de São Paulo. São Paulo.

FIALHO, S. Edson. Ilha de Calor: Reflexões Acerca de um Conceito. ACTA Geográfica, Ed. Esp. Climatologia Geográfica, p. 61-76, 2012.

FIALHO, S. Edson. O que é um Transecto e sua Utilização nos Estudos Climáticos. GEO UERJ, Vitória/ES, 2018.

GONZALES, D. E. G; KRÜGER, E. L. Impactos da Alteração no Albedo das Superfícies no Microclima e nos Níveis de Conforto Térmico de Pedestres em Cânions Urbanos. Ambiente Construído, Porto Alegre, v. 16, n. 3, p. 89 - 106, jul/set 2016.

LOMBARDO, M. A. Ilha de Calor nas Metrópoles. ed. Hucitec, São Paulo, 1985. 
MARQUES, D; GANHO, N; CORDEIRO, R. M. A. O Contributo de Estudos Climáticos à Escala Local para o Ordenamento Urbano: O Exemplo de Coimbra (Portugal). rev. $1^{\circ}$ Cong. Desenv. Reg. Cabo Vede, $2^{\circ}$ Cong. Lusófono Ciência Reg.

MENDONÇA, F; OLIVEIRA, I. M. D. Climatologia: Noções Básicas e Climas do Brasil. Ed. Oficina de Texto, São Paulo, 2007.

MINAKI, Cíntia. O clima urbano como indicador de qualidade ambiental: estudo de caso da paisagem urbana de Araçatuba/SP. 2013. xviii, 265 f. Tese (doutorado) - Universidade Estadual Paulista, Faculdade de Ciências e Tecnologia, 2014.

MONTEIRO, C. A. F. Clima Urbano. Ed. Contexto, São Paulo, SP, 2003.

MONTEIRO, C. A. F. Teoria e Clima Urbano. Tese de Livre Docência, USP, 219p. 1976.

NUNES, P. Ilha de Calor Urbana. Disciplina Planejamento Urbano, Faculdade Dom Bosco, Porto Alegre, RS, 2008.

OKE, T. R. Boundary Layer Climates. London: Routledge, 2002.

RIBEIRO, H. P. Ilha de Calor na Cidade de São Paulo: Sua Dinâmica e Efeitos na Saúde da População. Tese (Livre-docência em Gerenciamento Ambiental) Faculdade de Saúde Pública, Universidade de São Paulo, São Paulo, 1996.

ROCHA, M. Vinícius; FIALHO, S. Edson. Uso da Terra e Suas Implicações na Variação Termo-higrométrica ao Longo de um Transecto Campo-Cidade no Município de Viçosa. Revista de C. Humanas, Vol. 10, № 1, p. 64-77, jan./jun. 2010.

ROSS, L. S. Jurandyr; MOROZ, I. C. Mapa Geomorfológico do Estado de São Paulo. Mapas e Relatório. Departamento de Geografia da Universidade de São Paulo. FFLCH/USP e IPT/FAPESP 1997.

UTIMURA, Isabel. Conforto Térmico em Habitações de Favelas e possíveis Correlações com Sintomas respiratórios: O Caso do "Assentamento Futuro Melhor" - SP. Tese de Doutoramento FFLCH-USP, São Paulo-SP, 300 p, 2010.

WOLLMANN, et. Al. Variabilidade espacial da temperatura do ar com uso de transectos móveis em Tupanciretã/RS, sob domínios atmosféricos tropicais. Revista Ciência e Natureza - UFSM, Sta. Maria, Vol. 39, ed. Esp. p. 206 - 217, 2017.

\section{REFERÊNCIAS ELETRÔNICAS}

Câmara Municipal de São 2012. http://www.camara.sp.gov.br/blog/camara-comemora-59-anos-do-jardim-peri/. Acesso em: 20/04/2018.

Departamento de Trânsito de São Paulo. Frota Total de Veículos em São Paulo. 2018.

https://www.detran.sp.gov.br/wps/wcm/connect/portaldetran/detran/detran/est atisticastransito/sa-frotaveiculos/d28760f7-8f21-429f-b039-0547c8c46ed1.

Acesso em: 16/05/2018. 
Instituto Brasileiro de Geografia e Estatísticas. Operações Censitárias. 2010. https://censo2010.ibge.gov.br/materiais/guia-do-censo/operacao-

censitaria.html. Acesso em: 20/04/2018

Prefeitura de São Paulo. Dados Demográficos dos Distritos Pertencentes às Prefeituras $\quad 2017$. http://www.prefeitura.sp.gov.br/cidade/secretarias/regionais/casa_verde/noticia $\mathrm{s} / \mathrm{p}=47754$. Acesso em: 18/04/2018.

Instrutherm

Brasil.

2018.

http://www.instrumbrasil.com.br/laboratorio/datalogger/?gclid=EAIaIQobChMIp c-n-Mz72wIVEISRCh0pWgCIEAAYASAAEgI2CvD_BwE. Acesso em: 30/06/2018. 